\title{
Integrated chemical/physical and biological processes modelling Part 2 - Anaerobic digestion of sewage sludges
}

\author{
SW Sötemann, P van Rensburg, NE Ristow, MC Wentzel, RE Loewenthal and GA Ekama*
}

Water Research Group, Department of Civil Engineering, University of Cape Town, Rondebosch 7701, Cape Town, South Africa

\begin{abstract}
The development and validation of a two phase (aqueous-gas) integrated mixed weak acid/base chemical, physical and biological processes kinetic model for anaerobic digestion (AD) of sewage sludge are described. The biological kinetic processes for $\mathrm{AD}$ are integrated into a two phase subset of the three phase mixed weak acid/base chemistry kinetic model of Musvoto et al. (1997, 2000a,b,c). The approach of characterising sewage sludge into carbohydrates, lipids and proteins, as is done in the International Water Association (IWA) AD model No 1 (ADM1, Batstone et al., 2002), requires measurements that are not routinely available on sewage sludges. Instead, the sewage sludge is characterised with the COD, carbon, hydrogen, oxygen and nitrogen $(\mathrm{CHON})$ composition. The model is formulated in mole units, based on conservation of C, N, O, H and COD. The model is calibrated and validated with data from laboratory mesophilic anaerobic digesters operating from 7 to $20 \mathrm{~d}$ sludge age and fed a sewage primary and humus sludge mixture. These digesters yielded COD mass balances between 107 and $109 \%$ and $\mathrm{N}$ mass balances between 91 and $99 \%$, and hence the experimental data is accepted as reasonable. The sewage sludge is found to be 64 to $68 \%$ biodegradable (depending on the kinetic formulation selected for the hydrolysis process) and to have $\mathrm{C}_{3.5} \mathrm{H}_{7} \mathrm{O}_{2} \mathrm{~N}_{0.196}$ composition. For the selected hydrolysis kinetics of surface mediated reaction (Contois), with a single set of kinetic and stoichiometric constants, for all retention times good correlation is obtained between predicted and measured results for:

- COD

- free and saline ammonia (FSA),

- $\quad$ short chain fatty acids (SCFA),

- $\mathrm{H}_{2} \mathrm{CO}_{3}{ }^{*}$ alkalinity and $\mathrm{pH}$ of the effluent stream, and

- $\mathrm{CO}_{2}$ and $\mathrm{CH}_{4}$ gases in the gas stream.

The measured composition of primary sludge from two local wastewater treatment plants ranged between $\mathrm{C}_{3.38} \mathrm{H}_{7} \mathrm{O}_{1.91} \mathrm{~N}_{0.21}$ and $\mathrm{C}_{3.91} \mathrm{H}_{7} \mathrm{O}_{204} \mathrm{~N}_{0.16}$. The predicted composition is therefore within $5 \%$ of the average measured composition providing persuasive validation of the model.
\end{abstract}

Keywords: Anaerobic digestion, weak acid/base chemistry, kinetic modelling, sewage sludge

$\begin{array}{ll}\text { Abbreviations } \\ \text { Ac } & \text { Acetic acid/acetate } \\ \text { AD } & \text { Anaerobic digestion } \\ \text { ADM1 } & \text { Anaerobic Digestion Model No 1 } \\ \text { ASM1, } 2 & \text { Activated Sludge Models Nos. } 1 \text { or } 2 \\ \text { BD } & \text { Prefix for Biological anaerobic digestion processes } \\ \text { BEPR } & \text { Biological excess phosphorus removal } \\ \text { CED } & \text { Chemical equilibrium dissociation } \\ \text { CF } & \text { Cape Flats } \\ \text { CIP } & \text { Chemical ion pairing } \\ \text { COD } & \text { Chemical oxygen demand } \\ \text { CP } & \text { Chemical/physical } \\ \text { CPB } & \text { Chemical/physical/biological } \\ \text { FSA } & \text { Free and saline ammonia } \\ \text { IWA } & \text { International Water Association } \\ \text { K } & \text { Kelvin - absolute temperature scale } \\ \text { MW } & \text { Molecular weight } \\ \text { OrgN } & \text { Organic nitrogen } \\ \text { PGE } & \text { Physical gas exchange } \\ \end{array}$

* To whom all correspondence should be addressed. 证 +2721650 2588/0/4; fax: +27 216897471 ; e-mail: ekama@ebe.uct.ac.za Received 11 January 2005; accepted in revised form 25 April 2005.
$\mathrm{pH} \quad-$-ve log of the hydrogen ion activity

PMP Physical mineral precipitation

$\mathrm{Pr} / \mathrm{HPr} \quad$ Propionate/Propionic acid

SCFA Short chain fatty acid

TKN Total Kjeldahl nitrogen

TSS Total suspended solids

UCT University of Cape Town

UCTADM1 UCT Anaerobic Digester Model No. 1

VSS Volatile suspended solids

WAS Waste activated sludge

WWTP Wastewater treatment plant

\section{Symbols}

(1)b Endogenous respiration/death rate of organisms $\mathrm{C}_{\text {disgas }}$ Dissolved (aqueous) gas concentration in reactor liquid $(\mathrm{mol} / \ell)$

$\mathrm{C}_{\mathrm{hsgas}} \quad$ Head space gas concentration $(\mathrm{mol} / \mathrm{\ell})$

$\mathrm{C}_{\mathrm{T}} \quad$ Total inorganic carbon concentration

$\mathrm{C}_{\text {var }} \quad$ Coefficient of variation

$\mathrm{f}_{\mathrm{m}} \quad$ Monovalent ion activity coefficient

$\mathrm{f}_{\text {PSR }} \quad$ Fraction of COD removed by primary sedimentation

$\mathrm{f}_{\text {PSup }} \quad$ Fraction of unbiodegradable COD in the sewage sludge 
$\mathrm{f}_{\text {S'up }}, \mathrm{f}_{\text {S'us }} \quad$ Particulate and soluble unbiodegradable COD fraction. Additional subscripts $\mathrm{R}$ and $\mathrm{S}$ denote raw and settled wastewater.

$\mathrm{f}_{\text {Sbsa/Sbsf }} \quad$ Fraction fermentable COD that appears as VFA (0.607) in acidogenesis

${ }^{(2)} \mathrm{H}_{\mathrm{c}} \quad$ Dimensionless Henry's law constant. Additional ' (prime) denotes value adjusted for inoic strength effects.

$\mathrm{K}$ Constant for phase change from liquid to gas

$\mathrm{K}_{\mathrm{h}}, \mathrm{K}_{\mathrm{H}} \quad$ First order and first order specific hydrolysis rate constant

${ }^{(2)} \mathrm{K}_{\mathrm{H}} \quad$ Henry's law constant

$\mathrm{k}_{\mathrm{H} 2} \quad$ Hydrogen gas inhibition coefficient for high $p_{\mathrm{H} 2}$

${ }^{(1)} \mathrm{K}_{\mathrm{I}} \quad$ Hydrogen ion $\left(\mathrm{H}^{+}\right)$inhibition constant

${ }^{(2)} \mathrm{K}_{\mathrm{La}} \quad$ Overall liquid phase mass transfer rate coefficient

$\mathrm{K}_{\mathrm{La} \text { gas }} \quad$ Specific gas mass transfer rate

$\mathrm{k}_{\text {max }, \mathrm{HYD}} \quad$ Maximum specific rate in the saturation (Contois) hydrolysis equation

${ }^{(1)} \mathrm{K}_{\mathrm{r}}, \mathrm{K}_{\mathrm{f}} \quad$ Reverse and forward kinetic reaction rate constants. Additional compound subscripts denote reactants.

${ }^{(1)} \mathrm{K}_{\mathrm{S}} \quad$ Half saturation coefficient in the Monod organism growth equation

$\mathrm{K}_{\mathrm{SM}, \mathrm{HYD}} \quad$ Half saturation coefficient in Monod hydrolysis equation

$\mathrm{K}_{\mathrm{SS}, \mathrm{HYD}} \quad$ Half saturation coefficient in saturation (Contois) hydrolysis equation

${ }^{(1)} \mu_{\max } \quad$ Maximum specific rate in Monod organism growth equation

$\mu_{\text {max,HYD }} \quad$ Maximum specific rate in Monod hydrolysis equation

pK -ve log of the dissociation constant. Subscript $\mathrm{Pr}$ denote propionic acid. Subscripts $\mathrm{C} 1$ and $\mathrm{C} 2$ denote $1^{\text {st }}$ and $2^{\text {nd }}$ values of the inorganic carbon system.

$p \quad$ Partial pressure (atm). Subscripts $\mathrm{H} 2, \mathrm{CO} 2$ denote $\mathrm{H}_{2}$ and $\mathrm{CO}_{2}$ gases

$p_{\text {gas }} \quad$ Partial pressure of a gas (atm)

$\mathrm{P}_{\mathrm{atm}} \quad$ Atmospheric pressure

$\mathrm{P}_{\text {tot }} \quad$ Total gas pressure in head space

$\mathrm{q}_{\text {gas }} \quad$ Vent gas flow rate from the head space

$\mathrm{Q}_{\mathrm{i}}, \mathrm{Q}_{\mathrm{e}} \quad$ Digester influent and effluent flow

$\mathrm{Q}_{\text {gas }} \quad$ Total gas production

$\mathrm{R}^{\text {gas }} \quad$ Universal gas constant [0.08206 ( $\ell$.atm)/(mol.K)]

$\mathrm{R}^{2} \quad$ Correlation coefficient

$\mathrm{R}_{\mathrm{h}} \quad$ Hydraulic retention time

(1) $\mathrm{r} \quad$ Volumetric growth rate of organisms $(\mathrm{gCOD} /(\ell \cdot \mathrm{d})$

$r_{\text {gas }} \quad$ Rate of gas diffusion across head-space bio-reactor link

$\mathrm{r}_{\mathrm{HYD}}, \mathrm{r}^{*}{ }_{\mathrm{HYD}}$ Volumetric hydrolysis/acidogenesis rate in mole or COD units

$\mathrm{S} \quad$ General symbol for non AD biomass COD concentration $(\mathrm{gCOD} / \ell)$. First subscript $\mathrm{u}, \mathrm{b}$ or $\mathrm{t}$ denotes unbiodegradable, biodegradable or total. Second subscript $\mathrm{p}$ or $\mathrm{s}$ denotes particulate or soluble. Third subscript a or f denotes VFA or fermentable soluble COD. Last subscript $\mathrm{i}$ or e denotes influent or effluent.

$\mathrm{T}_{\mathrm{k}} \quad$ Temperature in Kelvin $=\mathrm{T}^{\circ} \mathrm{C}+273$

$\mathrm{V}_{\mathrm{d}}, \mathrm{V}_{\mathrm{h}} \quad$ Volume of anaerobic digester and its head-space respectively

(1)(2) Y Biomass yield coefficient

${ }^{(1)} \mathrm{Z} \quad$ Organism concentration in $\mathrm{gCOD} / \ell$

[ ] Concentration of compound in $\mathrm{mol} / \ell$

(1) Additional subscripts AD, AC, AM and HM (uppercase) are for acidogenic, acetogenic, acetoclastic methanogenic and hydrogenotrophic methanogenic organisms respectively. Lower case subscripts are the anabolic equivalent values.

(2) Additional subscripts $\mathrm{O} 2, \mathrm{CO} 2, \mathrm{NH} 3$ and $\mathrm{N} 2$ are the constants for $\mathrm{O}_{2}, \mathrm{CO}_{2}, \mathrm{NH}_{3}$ and $\mathrm{N}_{2}$ gases respectively. Additional' (prime) denotes value adjusted for inoic strength effects.

\section{Introduction}

Anaerobic digestion (AD) is one of the oldest biological waste treatment processes, dating back more than a century. With the development of digester heating and mixing, AD has established itself as the most common method of sludge stabilisation, and has proven to be effective also in reducing the volumes of sludge with the production of energy rich bio-gas. It has been shown that $\mathrm{AD}$ is an effective process for the treatment of a number of types of organic sludges, ranging from municipal waste activated (WAS) and primary sludges (Kayhanian and Tchobanoglous, 1992; Cout et al. 1994) to industrial organic sludges and agricultural slurries (Hill and Barth, 1977). In particular, the application of AD to the stabilisation of sewage sludges (primary, WAS and humus) is widespread, and this paper focuses on this application.

Despite its widespread application, the design, operation and control of anaerobic digesters treating sewage sludges is still based largely on experience or empirical guidelines. To aid the design, operation and control of (and research into) AD, a mathematical model would be an invaluable process evaluation tool. Mathematical models provide quantitative descriptions of the treatment system of interest that allow predictions of the system response and performance to be made. From these predictions, design and operational criteria can be identified to optimise the system performance. Mathematical models provide an integrated framework for the system which can give guidance to design, operation and research.

Recognising the potential usefulness of mathematical models, various researchers have developed such models to describe AD (e.g. McCarty, 1974, Hill and Barth, 1977; Gujer and Zehnder, 1983; Sam-Soon et al., 1991; Kiely et al., 1997, Batstone et al., 2002). The early models focussed primarily on the biological processes operating in an anaerobic digester. Although the importance of the interaction between the biological processes and the weak acid/base chemistry environment in which they operate was recognised early on, because of the effect of $\mathrm{pH}$ on the biological processes, modelling this interaction proved to be a far more complex problem than delineating the biological processes themselves. Initially the impact of the biological processes on $\mathrm{pH}$ was assessed graphically based on equilibrium chemistry principles of the carbonate weak acid/base system (e.g. Capri and Marais, 1975). The advent of computers and development of numerical algorithms made it easier to model the interaction based on single or two phase (aqueous-gas) weak acid/base chemistry equilibrium equations to estimate the $\mathrm{pH}$ in anaerobic digesters. The approach of Loewenthal et al. (1989, 1991) made it possible to include multiple mixed weak acid/base systems, both for estimating the digester $\mathrm{pH}$ and in the determination and interpretation of the commonly measured digester control parameters, short chain (volatile) fatty acids (SCFA) and alkalinity (Moosbrugger et al., 1992; Lahav and Loewenthal, 2000). The latest AD model (IWAADM1, Batstone et al., 2002) includes algebraic algorithms, based on equilibrium weak acid/ base chemistry and continuity of charge balances, that seek to model the environment in which the biological processes operate, to predict the $\mathrm{pH}$. These algebraic algorithms and calcula- 
tion of $\mathrm{pH}$ operate externally to the kinetic model structure. As alternative, dynamic equilibria equations for the weak acid/base systems are described (similar to the approach of Musvoto et al., 1997, 2000a). However, the weak acid/base water is not included so that $\mathrm{pH}$ is again algebraically calculated externally to the kinetic model, via the charge balance. Calculation of $\mathrm{pH}$ externally via the charge balance cannot deal simply with multiple weak acid/base systems in three phases (aqueous/gas/solid), where several minerals competing for the same species may precipitate simultaneously or sequentially (Musvoto et al., 2000a,c): In some anaerobic digestion systems precipitation of minerals is significant, either within the digester itself or in pipework leading from the digester so that the relevant chemical precipitation processes would require inclusion. For such situations, the biological processes and multiple weak acid/base systems in three phases should be modelled in an integrated way within the same kinetic model structure.

In the first paper of this series (Sötemann et al., 2005a), an integrated chemical (C), physical (P) and biological (B) processes model for the $\mathrm{N}$ removal activated sludge system was presented. This model was developed by integrating the biological processes of the International Water Association (IWA) Activated Sludge Model No 1 (ASM1, Henze et al., 1987) into a two phase (aqueous-gas) subset of the three phase mixed weak acid/ base CP model of Musvoto et al. (1997, 2000a,b,c), and included additionally gas exchange of $\mathrm{N}_{2}$. This paper describes the development of an integrated two phase (aqueous-gas) chemical (C), physical (P) and biological (B) processes AD model for sewage sludges, by integrating the biological processes for $\mathrm{AD}$ with the same two phase subset of the three phase CP model of Musvoto et al. (1997, 2000a,b,c). In a future paper, this AD model will be extended to include the third (solid) phase of mineral precipitation. In fact, the $\mathrm{N}$ removal activated sludge and $\mathrm{AD}$ models are two parts of a single larger model being developed for simulating the entire wastewater treatment plant (WWTP) on materials mass balance and continuity principles. It is planned to include also biological excess $\mathrm{P}$ removal (BEPR) and $\mathrm{AD}$ of $\mathrm{P}$ rich waste activated sludges in the WWTP model.

The AD model is built up in stages. First, the biological processes are defined and then these are integrated into the mixed weak acid/base model of Musvoto et al. (1997, 2000a,b,c). For ease of cross-referencing to the source papers, the same process and compound numbering system described in Part 1 will be used in this Part 2 (see Table 1 of Sötemann et al., 2005a).

\section{Biological processes of anaerobic digestion}

\section{Conceptual model}

In the literature there is considerable variation in conceptual schemes for describing the biological processes of AD with sewage sludge as influent, from simple two stage reaction schemes including only hydrolysis/acidogenesis and methanogenesis (Kiely et al., 1997) to the most commonly used six step reaction scheme as proposed by Gujer and Zehnder (1983).

In the reaction scheme of Gujer and Zehnder (1983) (Fig. 1), the hydrolysis process acts separately on three main groups of complex organics, viz. proteins, carbohydrates and lipids. These complex polymeric materials are hydrolysed by extracellular enzymes to soluble products that are small enough to allow their transport across the cell membrane. The products of the separate hydrolysis processes are amino acids, sugars and fatty acids respectively. These relatively simple, soluble compounds are fermented (acidogenesis) or anaerobically oxi-

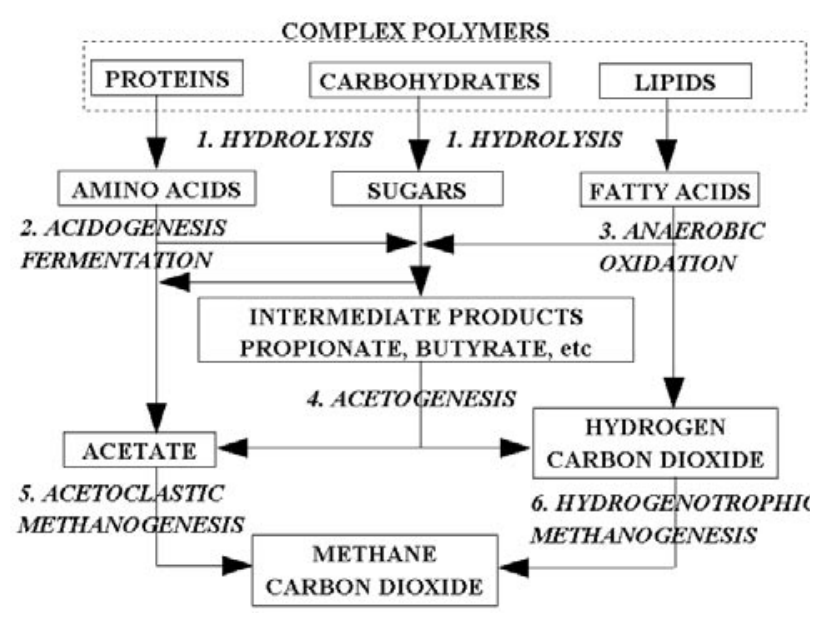

Figure 1

Anaerobic digestion processes scheme of Gujer and Zehnder (1983)

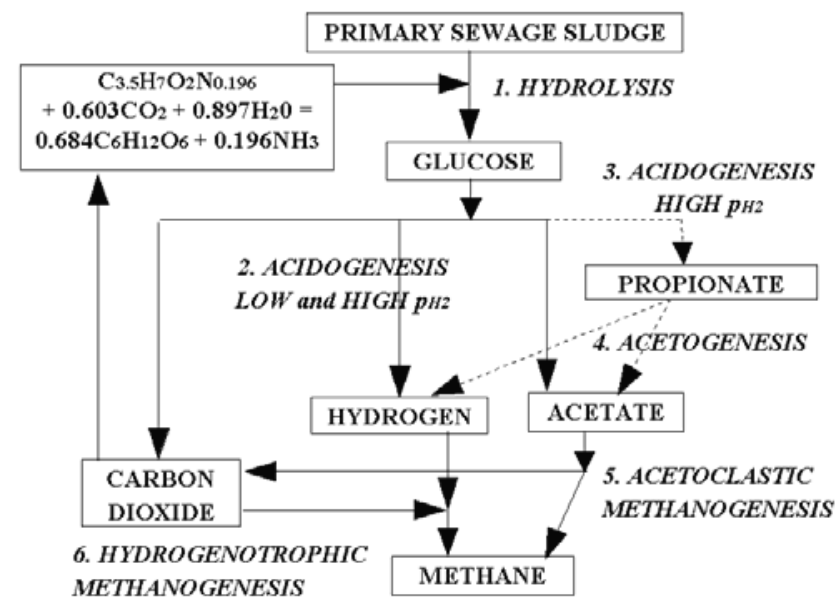

Figure 2

Anaerobic digestion processes scheme of University of Cape Town Anaerobic Digestion Model No 1 (UCTADM1) including (i) the effect of high hydrogen partial pressure on acidogenesis and (ii) $C O D$, carbon and nitrogen mass balances with a generic CHON sludge composition.

dised to short chain fatty acids (SCFAs) (acetate), alcohols, $\mathrm{CO}_{2}$, hydrogen and ammonia. A portion of the hydrolysis products are also converted to intermediate products (propionate, butyrate, etc.), which are then converted to acetate, hydrogen gas and $\mathrm{CO}_{2}$ through a process called acetogenesis. Lastly, methanogenesis occurs by hydrogen reduction with $\mathrm{CO}_{2}$ (hydrogenotrophic methanogenesis) and from acetate cleavage (acetoclastic methanogenesis).

The Gujer and Zehnder (1983) reaction scheme formed the basis for the AD model developed here, but with four main modifications (Fig. 2), viz.:

(1) Recognising that carbohydrate, protein and lipid measurements on sewage sludges are unlikely to be routinely available and indeed are difficult to do, the hydrolysis of the three separate organic materials was modified to a single hydrolysis process acting on a generic organic material representing sewage sludge $\left(\mathrm{C}_{\mathrm{X}} \mathrm{H}_{\mathrm{Y}} \mathrm{O}_{\mathrm{Z}} \mathrm{N}_{\mathrm{A}}\right.$, McCarty, 1974). This simplification is not unreasonable since the end products of hydrolysis and subsequent acidogenesis of the three organic groups 


\begin{tabular}{|c|c|c|}
\hline \multicolumn{3}{|c|}{$\begin{array}{l}\text { TABLE } 1 \\
\text { Biological processes included in the two phase anaerobic digestion model }\end{array}$} \\
\hline Process & Specific biological process & Organism group \\
\hline Hydrolysis & D1. Hydrolysis of $\mathrm{C}_{\mathrm{X}} \mathrm{H}_{\mathrm{Y}} \mathrm{O}_{\mathrm{Z}} \mathrm{N}_{\mathrm{A}}$ to "glucose" & Acidogens, $\mathrm{Z}_{\mathrm{AD}}$ \\
\hline \multirow[t]{5}{*}{ Growth } & D2. Acidogens on 'glucose' under low $\mathrm{p}_{\mathrm{H} 2}$ & Acidogens, $Z_{\mathrm{AD}}$ \\
\hline & D3. Acidogens on 'glucose' under high $\mathrm{p}_{\mathrm{H} 2}$ & Acidogens, $\mathrm{Z}_{\mathrm{AD}}$ \\
\hline & D5. Acetogens on propionic acid & Acetogens, $\mathrm{Z}_{\mathrm{AC}}$ \\
\hline & D7. Acetoclastic methanogens on acetic acid & Acetoclastic methanogens, $\mathrm{Z}_{\mathrm{AM}}$ \\
\hline & D9. Hydrogenotrophic methanogens on $\mathrm{H}_{2}$ & Hydrogenotrophic methanogens, $Z_{\mathrm{HM}}$ \\
\hline \multirow{4}{*}{$\begin{array}{l}\text { Death/ } \\
\text { Endogenous } \\
\text { decay }\end{array}$} & D4. Acidogens & Acidogens, $Z_{\mathrm{AD}}$ \\
\hline & D6. Acetogens & Acetogens, $\mathrm{Z}_{\mathrm{AC}}$ \\
\hline & D8. Acetoclastic methanogens & Acetoclastic methanogens, $Z_{\mathrm{AM}}$ \\
\hline & D10. Hydrogenotrophic methanogens & Hydrogenotrophic methanogens, $\mathrm{Z}_{\mathrm{HM}}$ \\
\hline
\end{tabular}

are essentially the same, namely SCFAs. In this approach, the $\mathrm{C}, \mathrm{H}, \mathrm{O}$ and $\mathrm{N}$ contents of sewage sludges are needed to determine the $\mathrm{X}, \mathrm{Y}, \mathrm{Z}$ and $\mathrm{A}$ values in $\mathrm{C}_{\mathrm{X}} \mathrm{H}_{\mathrm{Y}} \mathrm{O}_{\mathrm{Z}} \mathrm{N}_{\mathrm{A}}$; These were determined by simulation of measured data and direct measurement, see below. In follow-up work to extend the model to AD of waste activated sludges (including biological excess $P$ removal sludges) in 3 phases (liquid-gas-solid), i.e. including mineral precipitation, the $\mathrm{P}$ content of sewage sludges will be added to this formulation (i.e. $\mathrm{C}_{\mathrm{X}} \mathrm{H}_{\mathrm{Y}}$ $\left.\mathrm{O}_{\mathrm{Z}} \mathrm{N}_{\mathrm{A}} \mathrm{P}_{\mathrm{B}}\right)$.

(2) With the proposed single hydrolysis process, recognition of three separate hydrolysis products was no longer necessary. Accordingly, a single hydrolysis process and end product were included. This end product was chosen to be the idealised carbohydrate "glucose" for a number of reasons: The subsequent biological processes on "glucose" are well established and the acidogenic/fermentation process acting on "glucose" to convert it to SCFAs is unlikely ever to be rate limiting. Accordingly, in model application accumulation of 'glucose' will not occur, even under digester failure conditions. This implies that the "glucose" acts merely as an intermediate compound, which is acidified to SCFAs as soon as it is produced. In any event, because the end products of hydrolysis and acidogenesis in the scheme of Gujer and Zehnder (1983) (Fig. 1) are the same as in the revised scheme (Fig. 2), the net result is the same in both schemes. In order to maintain the $\mathrm{COD}, \mathrm{C}, \mathrm{H}, \mathrm{O}$ and $\mathrm{N}$ balances, water and carbon dioxide are taken up from the bulk liquid to generate the glucose from the sewage sludge (Fig. 2), and ammonia is released.

(3) As a consequence of accepting a single hydrolysis process, separate anaerobic oxidation of fatty acids does not need to be included.

(4) In the reaction scheme of Gujer and Zehnder (1983), a fixed proportion of hydrolysis end products are converted to intermediate SCFA (propionate, butyrate, etc.) and the balance directly to acetate. As an alternative, the influence of the hydrogen partial pressure $\left(p_{\mathrm{H} 2}\right)$ on acidogenesis of glucose to acetate and propionate as proposed by Sam - Soon et al. (1991) was included in the revised scheme. This provides a better description of AD behaviour under failure conditions. To include the proposals of Sam-Soon et al. (1991), the acidogenesis was divided into two processes - under high $p_{\text {H2 }}$ conditions, acetic and propionic acids are generated together with $\mathrm{H}_{2}$ and $\mathrm{CO}_{2}$; and under low $p_{\mathrm{H} 2}$ conditions, acetic acid only is generated together with $\mathrm{H}_{2}$ and $\mathrm{CO}_{2}$. In this revised scheme, generation of butyrate and higher SCFAs was not considered, because with sewage sludge as influent these usually are only found in minor concentrations, even under digester failure conditions.

\section{Mathematical model - UCTADM1}

Accepting the revised reaction scheme (Fig. 2), the biological processes mediated by the four recognised AD organism groups were included in the two phase (aqueous-gas) chemical (C), physical (P) and biological (B) anaerobic digestion model (UCTADM1, see Table 1). Following ASM1 for activated sludge systems (Henze et al., 1987), the processes were formulated either as hydrolysis or organism group growth processes. All four organism groups were accepted to be subject to endogenous respiration and so an endogenous mass loss process was included in the model for each group. It is recognised that the organism groups are not representative of a single organism species, but rather are "surrogates" representing all organism species performing a particular function of interest; this is similar to the approach followed for modelling of activated sludge systems (e.g. Dold et al., 1980, Henze et al., 1987). In formulating the model, since weak acid/base chemistry is included directly, all biological processes that act on weak acid/base species needed to be formulated in terms of the relevant dissociated or undissociated species (see below). This included both the stoichiometric consumption or production of weak acid/base species by the processes, and the formulation of the kinetic rate expressions. Whichever species is selected, in the production or consumption of weak acid/base species, because the weak acid/base chemistry is included directly, the model will automatically redistribute the weak acid/base species including the hydrogen ion $\left(\mathrm{H}^{+}\right)$and establish a new $\mathrm{pH}$

The 10 biological processes listed in Table 1 act on 14 compounds and cause changes in their concentrations. The changes in some compound concentrations may be directly measurable, but the changes in the non-measurable compound concentrations are inferred from the conceptual model of the processes (Fig. 2) and mass balance requirements. The compounds and processes of AD based on the reaction scheme of Fig. 2 are shown in the Petersen matrix format in Table 2, in which each row represents a biological process and each column a compound, and the stoichiometric relationships between the compounds and processes are listed at their intersection blocks, the process kinetic rates on the right hand side and the units of the compounds along the bottom. Note that all the compounds in Table 2 are specified as $\mathrm{mol} / \ell$, including the sewage sludge. The $\mathrm{mol} / \ell$ of the 
sewage sludge is calculated from its measured COD concentration and its $\mathrm{gCOD} / \mathrm{mol}$, which is calculated from its known composition, i.e. known $\mathrm{X}, \mathrm{Y}, \mathrm{Z}$ and $\mathrm{A}$ in $\mathrm{C}_{\mathrm{X}} \mathrm{H}_{\mathrm{Y}} \mathrm{O}_{\mathrm{Z}} \mathrm{N}_{\mathrm{A}}$ (see below). The AD organism concentrations for all four organism groups are also specified as $\mathrm{mol} / \ell$ based on a formulation of $\mathrm{C}_{5} \mathrm{H}_{7} \mathrm{O}_{2} \mathrm{~N}$, which has a molar mass of $113 \mathrm{~g} / \mathrm{mol}$ and a COD/VSS ratio of $1.42 \mathrm{mgCOD} / \mathrm{mgVSS}$ (McCarty, 1964). The gCOD, $\mathrm{gN}$ or $\mathrm{gH}_{2} \mathrm{CO}_{3}{ }^{*}$ Alk per mol of the compounds as appropriate are also given along the bottom of the matrix. If the $\mathrm{gCOD} / \mathrm{mol}$ ratios are multiplied by the corresponding stoichiometric value in the matrix and summed across a process, it will be found that these sums are zero, i.e. the COD mass balance applies across each process. The requirement to express the model compounds in mole units arises from the requirement to model $\mathrm{CO}_{2}$ production/utilisation (zero COD), which is essential for the weak acid/base chemistry part of the model.

\section{Stoichiometry of the biological processes}

The stoichiometry in the model was deduced directly from the biochemical stoichiometric equations of the processes. The metabolic pathways used by fermentative organisms for the degradation of carbohydrates to SCFAs are well defined. As noted above, for this reason amongst others, the biodegradable particulate COD entering the system was directly hydrolysed to the inter-

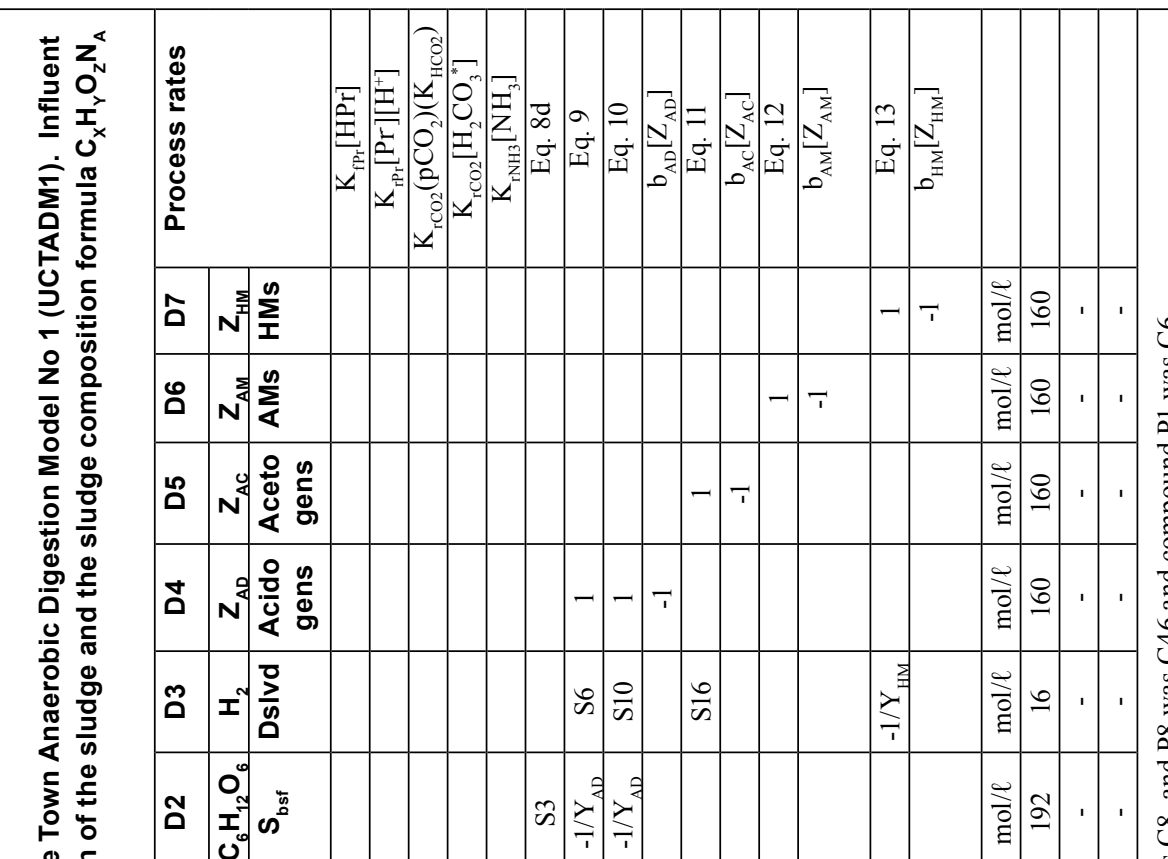

¿

ช

잉

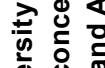

은

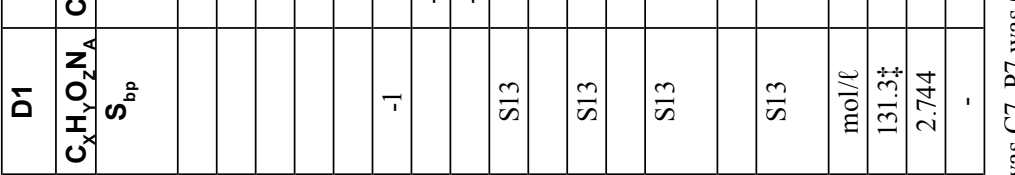

$\stackrel{0}{=} \mathrm{d}$

¿

\pm ơ

w

进

옹 巳

을 을

ठิ

过

部

तั

을

is

里

d ․

흐웡

ฮั

응

نو

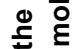

论.

ธำ

웜

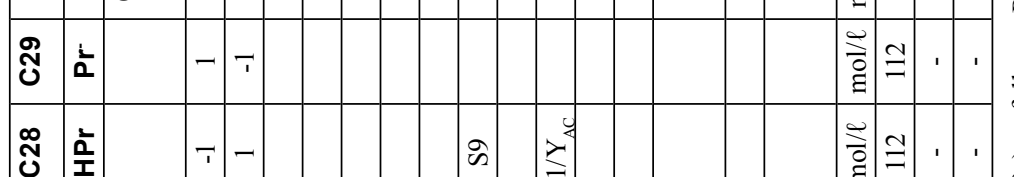

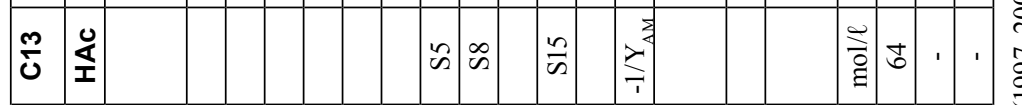

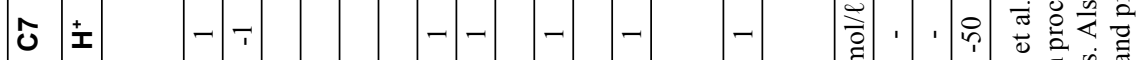

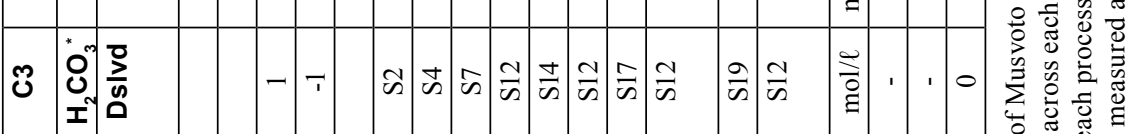

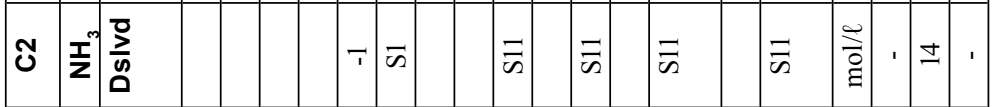

至语

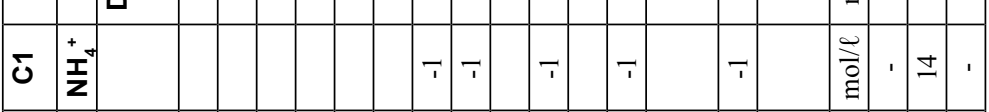

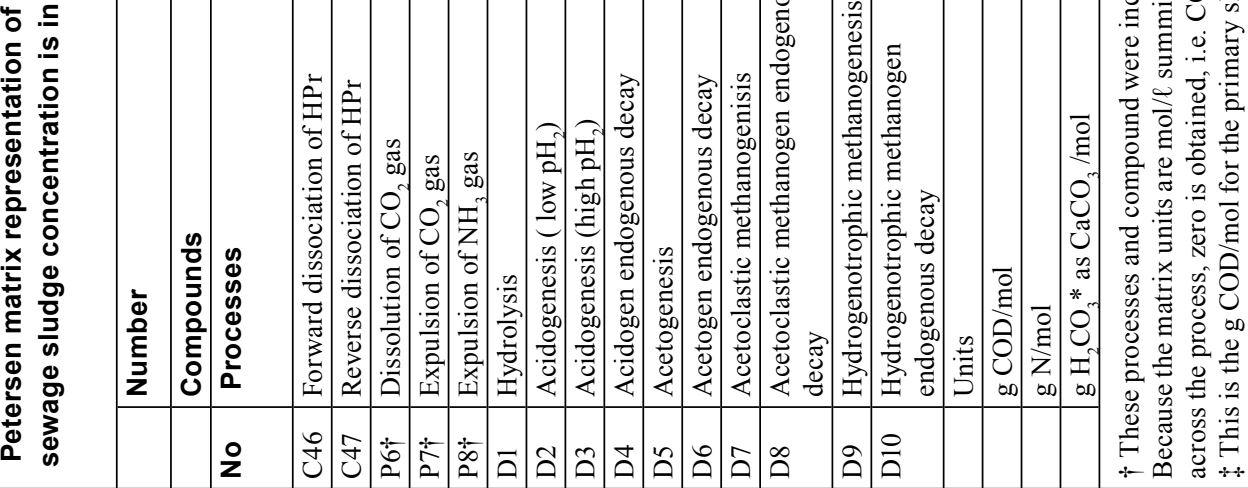




\begin{tabular}{|c|c|c|c|c|c|c|}
\hline \multicolumn{7}{|c|}{$\begin{array}{c}\text { TABLE } 3 \\
\text { Stoichiometry for acetogenesis and acetogen growth (Process D5 in Table 2). The S numbers in brackets cross } \\
\text { reference to the model Petersen matrix (Table 2). }\end{array}$} \\
\hline $\begin{array}{c}\mathrm{C} 1 / \mathrm{B} 10 \\
\mathrm{NH}_{4}{ }^{+}\end{array}$ & $\begin{array}{c}\mathrm{C} 3(\mathrm{~S} 14) \\
\mathrm{H}_{2} \mathrm{CO}^{3 *}\end{array}$ & $\begin{array}{l}\mathrm{C} 7 \\
\mathrm{H}^{+}\end{array}$ & $\begin{array}{c}\text { C13 (S15) } \\
\text { HAc }\end{array}$ & $\begin{array}{l}\mathrm{C} 28 \\
\mathrm{HPr}\end{array}$ & $\begin{array}{c}\text { D3 (S16) } \\
\mathrm{H}_{2} \\
\end{array}$ & $\begin{array}{l}\mathrm{D} 5 \\
\mathrm{Z}_{\mathrm{AC}}\end{array}$ \\
\hline moles & moles & moles & moles & moles & moles & moles \\
\hline-1 & $\frac{1-2 Y_{A C}}{Y_{A C}}$ & 1 & $\frac{1-\frac{3}{2} Y_{A C}}{Y_{A C}}$ & $-\frac{1}{Y_{A C}}$ & $\frac{3-4 Y_{A C}}{Y_{A C}}$ & 1 \\
\hline
\end{tabular}

mediate "glucose", from which the remainder of the products were formed. As an example for calculating the stoichiometry, consider the process of acetogenesis:

Acetogenesis (Process D5, Table 2) is the process whereby under low hydrogen partial pressure $\left(p_{\mathrm{H} 2}\right)$ the acetogens convert propionic acid (HPr) (generated by acidogenesis under high $\left.p_{\mathrm{H} 2}\right)$ to acetic acid (HAc). The stoichiometric equation for the acetogenesis reaction is:

$$
\mathrm{CH}_{3} \mathrm{CH}_{2} \mathrm{COOH}+2 \mathrm{H}_{2} \mathrm{O} \Rightarrow \mathrm{CH}_{3} \mathrm{COOH}+\mathrm{CO}_{2}+3 \mathrm{H}_{2}
$$

During acetogenesis, growth of acetogenic organisms $\left(\mathrm{Z}_{\mathrm{AC}}\right)$ takes place which can be stoichiometrically represented by:

$$
\begin{aligned}
& 3 \mathrm{CH}_{3} \mathrm{CH}_{2} \mathrm{COOH}+\mathrm{CO}_{2}+2 \mathrm{NH}_{4}^{+} \\
& \Rightarrow 2 \mathrm{C}_{5} \mathrm{H}_{7} \mathrm{O}_{2} \mathrm{~N}+4 \mathrm{H}_{2} \mathrm{O}+\mathrm{H}_{2}+2 \mathrm{H}^{+}
\end{aligned}
$$

Note that in Eqs. 1 and 2:

- $\mathrm{CO}_{2}$ is utilised as an additional carbon source - in all $\mathrm{CO}_{2}$ consumption/production the undissociated carbonate species $\mathrm{H}_{2} \mathrm{CO}_{3} *$ acts as source/sink respectively,

- ammonium is the nitrogen source for organism growth under normal operating conditions and $\mathrm{pH}(6.5<\mathrm{pH}<7.5)$ of an anaerobic digester, the ammonium species $\left(\mathrm{NH}_{4}^{+}\right)$ dominates over the ammonia species $\left(\mathrm{NH}_{3}\right)$ so that using ammonia as the $\mathrm{N}$ species for organism growth can cause numerical instability in solution procedures for the model,

- the undissociated propionic acid species is used as substrate source, in agreement with observations in the literature, and

- the chemical formulation for organisms is assumed to be $\mathrm{C}_{5} \mathrm{H}_{7} \mathrm{O}_{2} \mathrm{~N}$, which is the formulation generally accepted to represent organism active mass in activated sludge (WRC, 1984).

Accepting that $\mathrm{Y}_{\mathrm{ac}}$ mol of acetogen organisms are formed (i.e. the anabolic yield of acetogens), Eq. 2 can be rewritten as:

$$
\begin{aligned}
& \frac{3 \mathrm{Y}_{a c}}{2} \mathrm{CH}_{3} \mathrm{CH}_{2} \mathrm{COOH}+\frac{Y_{a c}}{2} \mathrm{CO}_{2}+\mathrm{Y}_{a c} \mathrm{NH}_{4}^{+}- \\
& \Rightarrow Y_{a c} \mathrm{C}_{5} \mathrm{H}_{7} \mathrm{O}_{2} \mathrm{~N}+2 \mathrm{Y}_{a c} \mathrm{H}_{2} \mathrm{O}+\frac{Y_{a c}}{2} \mathrm{H}_{2}+Y_{a c} \mathrm{H}^{+}
\end{aligned}
$$

Adding Eqs 1 and 3 and dividing by $\mathrm{Y}_{\mathrm{ac}}$ yields:

$$
\begin{aligned}
& \frac{1+\frac{3 Y_{a c}}{2}}{Y_{a c}} \mathrm{CH}_{3} \mathrm{CH}_{2} \mathrm{COOH}+\frac{2\left(1-Y_{a c}\right)}{Y_{a c}} \mathrm{H}_{2} \mathrm{O}+\mathrm{NH}_{4}^{+} \\
& \Rightarrow \frac{1}{Y_{a c}} \mathrm{CH}_{3} \mathrm{COOH}+\mathrm{C}_{5} \mathrm{H}_{7} \mathrm{O}_{2} \mathrm{~N}+\frac{1-\frac{Y_{a c}}{2}}{Y_{a c}} \mathrm{CO}_{2}+\frac{3+\frac{Y_{a c}}{2}}{Y_{a c}} \mathrm{H}_{2}+H^{+}
\end{aligned}
$$

Recognising that in Eq. 4 the "true" acetogen yield ( $\mathrm{Y}_{\mathrm{AC}}$, mole organism/mole propionate) is $\mathrm{Y}_{\mathrm{ac}} /\left(1+3 / 2 \mathrm{Y}_{\mathrm{ac}}\right)$, and substituting $\mathrm{Y}_{\mathrm{AC}}$ into Eq. 4 and solving gives:

$$
\begin{aligned}
& \frac{1}{Y_{A C}} \mathrm{CH}_{3} \mathrm{CH}_{2} \mathrm{COOH}+\frac{\left(2-5 Y_{A C}\right)}{Y_{A C}} \mathrm{H}_{2} \mathrm{O}+\mathrm{NH}_{4}^{+} \\
& \Rightarrow \frac{1-\frac{3}{2} Y_{A C}}{Y_{A C}} \mathrm{CH}_{3} \mathrm{COOH}+\mathrm{C}_{5} \mathrm{H}_{7} \mathrm{O}_{2} \mathrm{~N}+\frac{1-2 Y_{A C}}{Y_{A C}} \mathrm{CO}_{2}+\frac{3-4 Y_{A C}}{Y_{A C}} \mathrm{H}_{2}+H^{+}
\end{aligned}
$$

The stoichiometry for acetogenesis and acetogen growth was extracted from Eq. 5 directly, and is summarised in Table 3. Note that compounds that are utilised (reactants, left hand side of Eq. 5) are negative (reduction), while compounds produced (products, right hand side of Eq. 5) are positive (production), that $\mathrm{H}_{2} \mathrm{O}$ has been included in Eq. 5 for an element balance, but is not included directly in Table 3 , and that there is a net production of $\mathrm{CO}_{2}$ expressed as $\mathrm{H}_{2} \mathrm{CO}_{3} *$ in the kinetic model $\left(1 / \mathrm{Y}_{\mathrm{AC}}>2\right)$. Following this procedure, the stoichiometries for the remaining processes were derived and are summarised in Table 4.

In the hydrolysis process, the biodegradable particulate organics measured as $\mathrm{COD}\left(\mathrm{S}_{\mathrm{bp}}\right)$ in the sewage sludge are first changed to mole units "outside" of the kinetic model, i.e. matrix, by dividing by the $\mathrm{COD} / \mathrm{mol}$ ratio $=\{(\mathrm{Y}+4 \mathrm{X}-2 \mathrm{Z}-$ $\left.3 \mathrm{~A}) \cdot \mathrm{MW}_{\mathrm{O} 2} / 4\right\}$, with $\mathrm{MW}_{\mathrm{O} 2}$ being the molecular weight of $\mathrm{O}_{2}=32$ $\mathrm{g} / \mathrm{mol}$. Thereafter, the sewage sludge biodegradable particulate organics measured as moles $\left(\mathrm{S}_{\mathrm{bp}}\right)$ are transformed to the intermediate organic "glucose" also as moles $\left(\mathrm{S}_{\mathrm{bs}}\right)$. This process is crucial in anaerobic digestion modelling, as the amount of "glucose" formed will determine the amount of the end products $\left(\mathrm{CH}_{4}, \mathrm{CO}_{2}\right.$ and biomass $)$ in a stable digester. To develop the stoichiometry for the hydrolysis process, the stoichiometric reaction was separated into two half reactions, effectively the redox half reactions, which were added based on an electron (COD) balance. In setting up the conversion of the primary sludge COD to mole units and the two subsequent half reactions in the transformation to the intermediate "glucose", the chemical formulation for the sewage sludge was kept as a variable, i.e. $\mathrm{C}_{\mathrm{X}} \mathrm{H}_{\mathrm{Y}} \mathrm{O}_{\mathrm{Z}} \mathrm{N}_{\mathrm{A}}$, to allow the composition of the influent sewage sludge to the AD to be easily changed (McCarty, 1974). The formulation for the sewage sludge was assumed to be the same for all sewage sludge fractions (i.e. biodegradable and unbiodegradable), and to remain constant with degradation. This gives the stoichiometric reaction for sewage sludge hydrolysis as:

$$
\begin{aligned}
& C_{X} H_{Y} O_{Z} N_{A} \Rightarrow \frac{Y+4 X-2 Z-3 A}{24} C_{6} H_{12} O_{6} . \\
& +A N H_{3}+\frac{Y-4 X+2 Z-3 A}{4} H_{2} O+\frac{2 Z+3 A-Y}{4} \mathrm{CO}_{2}
\end{aligned}
$$

In the death/endogenous decay processes for the four organism groups (Table 4), it was accepted that the organisms die releasing biodegradable particulate organics $\left(\mathrm{S}_{\mathrm{bp}}\right)$, which are assumed to have the same formulation as the sewage sludge, i.e. $\mathrm{C}_{\mathrm{X}} \mathrm{H}_{\mathrm{Y}}$. $\mathrm{O}_{\mathrm{Z}} \mathrm{N}_{\mathrm{A}}$ with $\mathrm{CO}_{2}, \mathrm{H}_{2} \mathrm{O}$ and $\mathrm{NH}_{3}$ released or taken up from the bulk 